\title{
A new genus and species of Dermestidae (Coleoptera) from the Eckfeld Maar crater (Middle Eocene, Germany)
}

\author{
JIŘí HÁVA \& TORSTEN WAPPLER
}

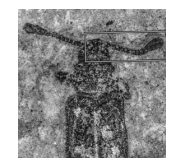

\begin{abstract}
Eckfeldattagenus eocenicus gen. et sp. nov. is described from the Middle Eocene Eckfeld Maar (Germany) on the basis of completely preserved specimens, representing one of the rare reports of fossil skin beetles (Coleoptera: Dermestidae: Attageninae). The new genus and species differs from all other Dermestidae by the very flat body form and pronotum, and its unique structure of the antennal club and the wrinkled elytral surface. $\bullet$ Key words: taxonomy, new genus, new species, fossil, Coleoptera, Dermestidae, Germany.
\end{abstract}

HÁVA, J. \& WAPPLER, T. 2014. A new genus and species of Dermestidae (Coleoptera) from the Eckfeld Maar crater (Middle Eocene, Germany). Bulletin of Geosciences 89(1), 67-74 (1 figure, appendix). Czech Geological Survey, Prague. ISSN 1214-1119. Manuscript received July 24, 2013; accepted in revised form October 23, 2013; published online December 12, 2013; issued January 21, 2014.

Jiři Háva, Department of Forest Protection and Entomology, Faculty of Forestry and Wood Sciences, Czech University of Life Sciences, Kamýcká 1176, CZ-165 21, Prague 6-Suchdol, Czech Republic •Torsten Wappler (corresponding author), Steinmann Institut für Geologie, Mineralogie und Paläontologie, Universität Bonn, Nussallee 8, 53115 Bonn, Germany; twappler@uni-bonn.de

Dermestidae commonly referred to as skin, larder and carpet beetles are characterized by a variety of ecological habits and a fascinating biology. Most genera are scavengers that feed on dry animal or plant material such as skin or pollen, animal hair, feathers, dead insects or natural fibers. They are even widely used to clean bones during the preparation of skeletons for osteological studies and forensic entomological. In the literature, the traces left on skeletal remains by the family Dermestidae have been documented for dinosaurs (Paik 2000, Roberts et al. 2007, Britt et al. 2008, Chin \& Bishop 2008, Bader et al. 2009) and extinct mammals (Martin \& West 1995, Kaiser 2000, Laudet \& Antoine 2004, Fejfar \& Kaiser 2005).

The cosmopolitan beetle family Dermestidae comprises more than 1460 described species (Háva 2003, 2013). According to a cladistic-based analysis of higher categories within the family Dermestidae (Lawrence \& Slipinski 2005, Kiselyova \& McHugh 2006), six subfamilies could be recognized: Dermestinae (including Marioutinae), Thorictinae, Trinodinae (including Thylodriadinae), Orphilinae, Attageninae and Megatominae; whereas only members of the Thorictinae are yet unknown from the fossil record. The geological history of the family was summarized by Háva \& Prokop (2004) and Kirejtshuk et al. (2009), with new information appended in the present contribution (appendix). The earliest fossils assigned tentatively to Dermestidae are isolated elytra from the Triassic deposits of Queensland, described by Dunstan (1923), but the assignment of these fossils was doubted by Háva \& Prokop (2004). The first definitive remains of the family have been recorded from the Lower Cretaceous Lebanese amber (Kirejtshuk et al. 2009). However, the majority of fossil dermestids were described from inclusions in Baltic (40-35 Ma BP) and Dominican Amber (20-17 Ma BP) - most of these are representing relatively modern groups, thereby relating more to questions of Tertiary biogeography than to higher-level branching patterns (Kiselyova \& McHugh 2006).

Herein we provide the description of a new Paleogene dermestid beetle from the Middle Eocene Eckfeld Maar. This deposit has produced a broad spectrum of fossils ranging from organic molecules, micro-organisms, aquatic invertebrates, plants and insects and their varied associations, to a wide range of vertebrates including articulated mammals exhibiting soft tissue preservation and gut contents (e.g., Lutz et al. 2010). The new species belongs to the Attageninae of the Dermestidae and is placed in a new genus most probably closely related to the extant genus Attagenus Latreille, 1802.

\section{Material and methods}

The Fossillagerstätte of Eckfeld is a deposit of a maar lake, which was formed during the early middle Eocene. The 
basin was initially formed by volcanic explosions, resulting in deep depressions on top of diatremes that was soon occupied by a lake. Following early stages with succeeding volcanoclastic and predominantly siliciclastic sedimentation, the lake became meromictic and the finely laminated bituminous claystone ("oilshale") was formed in the quiet anoxic bottom layer of the lake. The oilshale contains biomarkers and lithified bacteria, algae, a great diversity of tracheophytes, numerous arthropods, few molluscs and a wide range of vertebrates, documenting a highly diverse terrestrial flora and fauna representing an ecosystem towards the end of the middle Eocene (e.g., Neuffer et al. 1996; Lutz et al. 1998, 2010; Wilde \& Frankenhäuser 1998; Lutz \& Neuffer 2000; Wappler 2002, 2003a, b; Wappler \& Engel 2003, 2006; Wappler \& Andersen 2004; Wappler et al. 2004, 2005; Wappler \& Heiss 2006; Wappler \& Petrulevičius 2007; Petrulevičius et al. 2008; Dlussky et al. 2008, 2009). The Eckfelder Maar insect taphocoenosis contains a total of nearly 4700 fossil specimens. Most of them are in good condition with a potential for exceptional details of preservation. This fossil record documents a highly diverse terrestrial fauna and flora, while aquatic life is rather poorly represented. The insect taphocoenosis is predominantly composed of Coleoptera (84\%) (e.g., Lutz 1993, Wappler 2003a, b).

The crater structure at the Eckfeld Maar near Manderscheid, Eifel, Germany, originally had a diameter of $900 \mathrm{~m}$ and a depth of about $170 \mathrm{~m}$. The depth of the maar lake initially exceeded $110 \mathrm{~m}$ and might have reached $150 \mathrm{~m}$ (Pirrung et al. 2001). Rapid sedimentation over a 250.000 year period combined with anoxic alkaline conditions resulted in the absence of bioturbation and explains the perfect preservation of fossils within the oil-shale laminae (Mingram 1998).

Biochronologically the biota of the Eckfeld Maar represent the late Geiseltalium of the European Land Mammal Ages (ELMA), which corresponds to the middle part of the Lutetian of the global geochronological time scale (Franzen 1993). Argon ${ }^{40 / 39}$ Ar dating of basalt from the diatreme breccia underlying the lake sediments resulted in an age of $44.3 \pm 0.4 \mathrm{Ma}$ at Eckfeld (Mertz et al. 2000).

The specimens examined in the present work were gathered from the collection of the Naturhistorisches $\mathrm{Mu}$ seum Mainz, Landessammlung für Naturkunde Rheinland-Pfalz (NHMM). The type specimens are equipped with red, printed labels bearing the text as follows: "HOLOTYPE (or PARATYPE, respectively), Eckfeldattagenus eocenicus gen. et sp. nov. J. Háva \& T. Wappler det. 2013".

The specimens were studied by immersing the slab in glycerine to prevent oxidation. All metrics were made using an ocular micrometer and are given in millimetres. The nomenclature of dermestids is based on the interpretations of Lawrence \& Slipinski (2005) and Háva (2007).

\section{Systematic palaeontology}

Family Dermestidae

Subfamily Attageninae

Eckfeldattagenus gen. nov.

Figure 1

Type species. - Eckfeldattagenus eocenicus sp. nov. (by monotypy).

Diagnosis. -

Adult female: Body length 5.5-6.3 mm. The antennae consist of the 11 antennomeres, antennal club consist of two antennomeres (Fig. 1D). Last antennal antennomere is long, oval. Pronotum is long trapezoidal, with a clear wrinkled surface structure. Elytra long, parallel, with a clear wrinkled structure.

Adult male: Externaly similar to female, but differs by the structure of antennae, with the $10^{\text {th }}$ segment being slightly more prolonged (Fig. 1F, G).

Remarks. - Eckfeldattagenus is similar to genera belonging to the Attageninae and in particular to the genus Attagenus according to a Prosternum not forming a "collar", therefore, mouthparts are free, but on the other hand it differs from all other Dermestidae by the very flat body form, the outline of the pronotum, and its unique structure of the antennal club and the wrinkled elytral surface.

A key to the genera is given below:

1(5) antennomeres of antennal club compact

3(4) antennal club consist Eckfeldattagenus gen. nov. of two antennomeres

4(3) antennal club consist Attagenus Latreille, 1802 of three antennomeres

5 (1) antennomeres of antennal club loosely joined

6(7) cuticle bicolorous Novelsis Casey, 1900 or unicolorous with bicolorous pubescence

7(6) cuticle and pubescence unicolorous, terminal antennomere very long, arenicollis species

8(9) profemora stout Araphonotos Beal \& Kadej, 2008 9(8) profemora slender Sefrania Pic, 1899

Eckfeldattagenus gen. nov. differs from the genus Egidyella Reitter, 1899 (tribe Egidyellini) by the five visible abdominal ventrites (in the genus Egidyella six ventrites are visible).

Etymology. - The new generic name is a combination of Eckfeld (type locality from were the specimens are found), and Attagenus, type genus for one of the most abundant pests in stored products. The gender is masculine. 

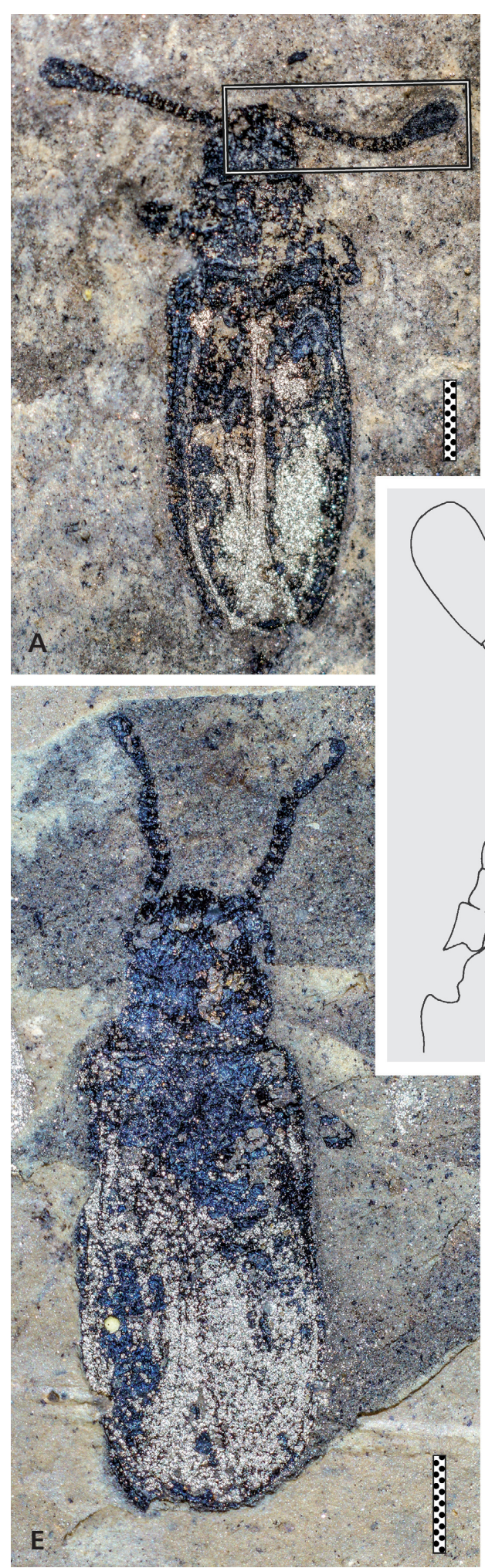
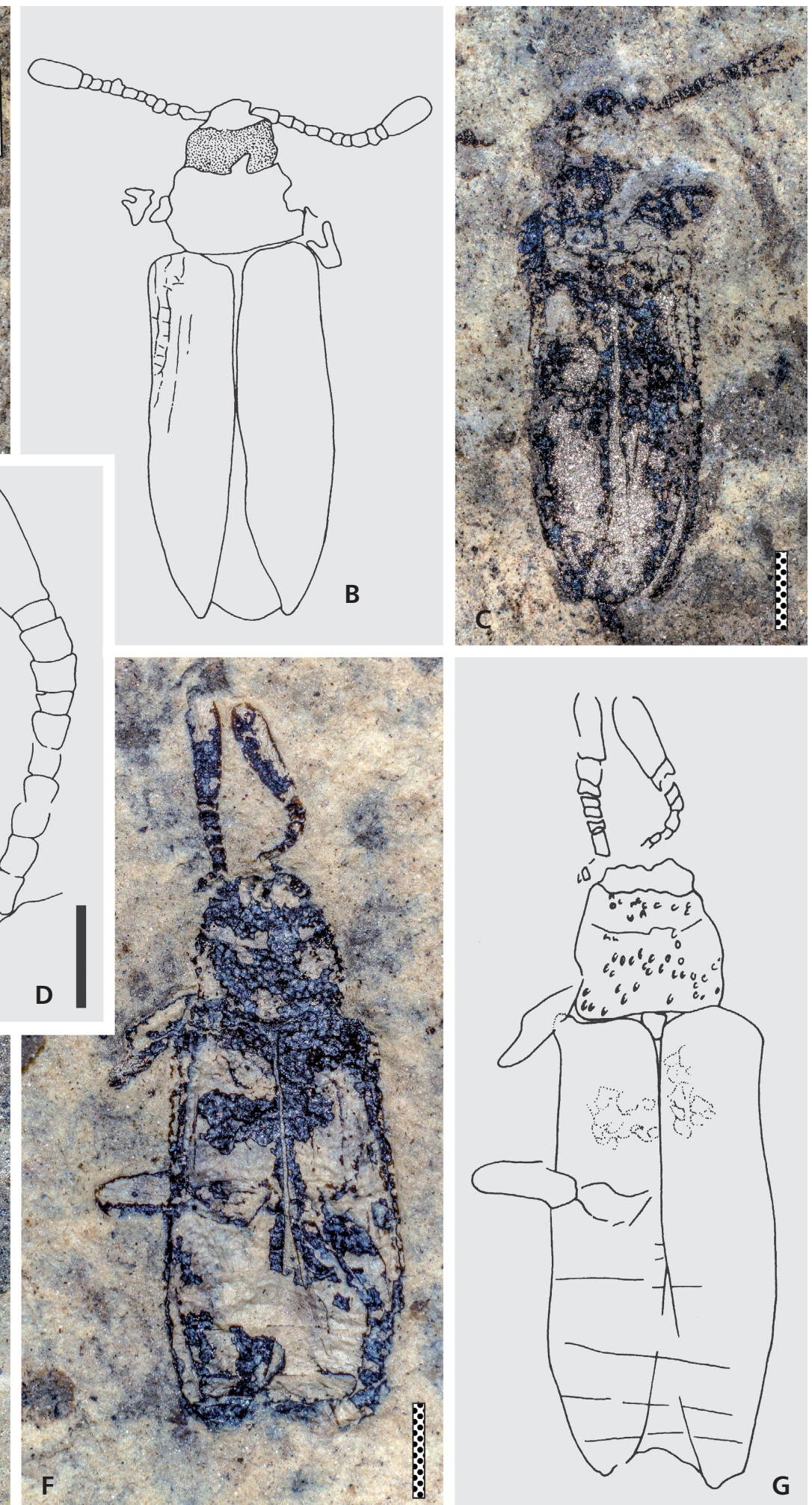

Figure 1. Eckfeldattagenus eocenicus gen. et sp. nov. • A - holotype (PE 2000/995a, LS). B - habitus diagram of A. • C - counterpart of holotype $(\mathrm{PE} 2000 / 995 \mathrm{~b}, \mathrm{LS}) \cdot \bullet \mathrm{D}$ - detail of antennae in A. $\bullet \mathrm{E}$ - paratype (PE 2000/996a, LS). $\mathrm{F}$ - paratype (PE 2000/997a, LS), arrows indicating the presences of relatively short and thin hairs. $\bullet \mathrm{G}$ - habitus diagram of F. Dotted scale bar $=1 \mathrm{~mm}$; solid scale bar $=0.5 \mathrm{~mm}$. 


\section{Eckfeldattagenus eocenicus sp. nov.} Figure 1

2003a Attagenus? sp. indet. Wappler; p. 95, abb. 64, pl. 11, fig. h, i.

2003b Attagenus? sp. indet. Wappler; p. 95, abb. 64, pl. 11, fig. h, i.

Type material. - Holotype (female) (PE 2000/995 a+b). Paratype: 1 spec. (female) (PE 2000/996 a+b), 1 spec. (male) (PE 2000/997 a+b). The type material is deposited in the Naturhistorisches Museum Landessammlung für Naturkunde Rheinland-Pfalz, Mainz, Germany.

Type locality. - Eckfeld Maar near Manderscheid, Eifel Mountains, Germany.

Stratigraphic occurrence. - Middle Eocene (ELMA Geiseltalian, MP13, $44.3 \pm 0.4 \mathrm{Ma})$.

Diagnosis. - As for the genus (vide supra).

Description. - Holotype measurements: total length $6.3 \mathrm{~mm}$, pronotum length $0.9 \mathrm{~mm}$, elytra length $4.1 \mathrm{~mm}$, antennae length $4.2 \mathrm{~mm}$, terminal antennomere length $0.7 \mathrm{~mm}$. The antennae consist of the 11 antennomeres, with a twosegmented antennal club. Last antennal antennomere is long, oval, and covered with dark, relatively short and thin subrecumbent hairs. Pronotum is long trapezoidal, with a clear wrinkled surface structure. Elytra long, parallel, with a clear structure wrinkled surface.

Etymology. - Eocenicus in reference to the Eocene age of the fossil.

Discussion. - Because of the preservation style, compression fossils cannot be easily compared to amber fossils or extant genera and species. Nonetheless, they can be diagnosed moderately well and differentiated with reasonable certainty from other extinct and extant genera. In some aspects, Eckfeldattagenus resembles members of the related genus, Attagenus Latreille, 1802 (vide supra). The latter contains about 180 recent species. Only eight fossil species are known worldwide; two species from Early Oligocene deposits in Colorado (A. aboriginalis Wickham, 1913 and A. sopitus Scudder, 1900), one species from Middle Miocene deposit in Germany (A. extinctus Heyden \& Heyden, $1865)$, four species from the Eocene Baltic amber (A. hoffeinsorum Háva, Prokop \& Herrmann, 2006a, A. obesus Háva, Prokop \& Herrmann, 2008, A. balticus Háva, Prokop \& Herrmann, 2008 and A. yantarnyi Háva \& Bukejs, 2012), and one species from Dominican amber (A. ambericus Háva \& Prokop, 2004). The newly described species differs from all fossil and recent species by the presence of very flat form of the body, a unique structure of the antennal club, indicating even some sexual dimorphism expressed by the length of the $10^{\text {th }}$ antennomer, and a more elongated, trapezoidal outline of the pronotum.

A comparison with the three described compression fossils Attagenus aboriginalis Wickham, 1913 [Colorado (Early Oligocene: Florissant)], Attagenus extinctus C. Heyden \& L. Heyden, 1865 [Germany (Middle Miocene)] and Attagenus sopitus Scudder, 1900 [(Early Oligocene: Florissant)], reveals that E. eocenicus gen. et sp. nov. differs mainly by the following characters: (1) body maximum length 5.5-6.3 mm, long, parallel; (2) antennae very long, antennal club composed of two antennomeres in male and two in female (Attagenus antennal club consists of three antennomeres).

\section{Conclusions}

1. Tertiary fossils of dermestid beetles are clearly more related to the extant fauna even though the two Cretaceous records represent members of extant families (comp. appendix). Interestingly, basalmost members of the Thorictinae, sister group to the remainder of Dermestidae are completely absent from the fossil record yet.

2. Although cosmopolitan in distribution, dermestid beetles species are most active during warmer climate conditions (e.g., Klok \& Harrison 2013, fig. 5).

3. The temperature requirements of dermestids did not conflict with the interpretations of Middle Eocene climatic conditions in the Eifel region based on the macrobotanical record. Grein et al. (2011) and Wappler et al. (2012) concluded that during middle Eocene climate at the Central European locality the mean annual temperature was in the order of above $20^{\circ} \mathrm{C}$, probably around $22^{\circ} \mathrm{C}$. The summers were rather hot with temperatures of the warmest month between $24.7^{\circ} \mathrm{C}$ and $27.9^{\circ} \mathrm{C}$. It is interesting, therefore, that the majority of insect species from the Eckfeld Maar are today found in the Southern Hemisphere but are known from Cenozoic fossils in Europe and other parts of the Northern Hemisphere (e.g., Wappler 2003a, p. 181ff).

\section{Acknowledgements}

We are very indebted to Herbert Lutz (Naturhistorisches Museum Landessammlung für Naturkunde Rheinland-Pfalz, Mainz, Germany) for providing to the interesting material for study and to Thomas Engel for taking photos of the specimens. The authors also thank the reviewers Bo Wang, Nanjing, and André Nel, Paris, for their critical reading of the manuscript and constructive suggestions. This is "Fossilfundstätte Eckfelder Maar (MittelEozän)" contribution No. 137. 


\section{References}

BAdER, K.S., Hasiotis, S.T. \& Martin, L.D. 2009. Application of forensic science techniques to trace fossils on dinosaur bones from a quarry in the Upper Morrison Formation, northeastern Wyoming. Palaios 24, 140-158.

DOI 10.2110/palo.2008.p08-058r

BEAL, R.S. 1972. A new fossil Cryptorhopalum (Dermestidae: Coleoptera) from Tertiary amber of Chiapas, Mexico. Journal of Palaeontology 46, 317-318.

Britt, B.B., Scheetz, R.D. \& Dangerfield, A. 2008. A suite of dermestid beetle traces on dinosaur bone from the Upper Jurassic Morrison Formation, Wyoming, USA. Ichnos 15, 59-71. DOI 10.1080/10420940701193284

Chin, K. \& Bishop, J.R. 2008. Exploited twice: bored bone in a theropod coprolite from the Jurassic Morrison Formation of Utah, U.S.A., 379-387. In Bromley, R.G., Buatois, L.A., Mángano, G., Genise, J.F. \& Melchor, R.N. (eds) Sediment-organism Interactions: A Multifaceted Ichnology. SEPM Special Publication 88.

Cockerell, T.D.A. 1917. Arthropods in Burmese Amber. Psyche 24, 40-45. DOI 10.1155/1917/83242

Dlussky, G.M., Wappler, T. \& Wedmann, S. 2008. New middle Eocene formicid species from Germany and the evolution of weaver ants. Acta Palaeontologica Polonica 53, 615-626. DOI 10.4202/app.2008.0406

Dlussky, G.M., Wappler, T. \& Wedmann, S. 2009. Fossil ants of the genus Gesomyrmex Mayr (Hymenoptera, Formicidae) from the Eocene of Europe and remarks on the evolution of arboreal ant communities. Zootaxa 2031, 1-20.

Dunstan, B. 1923. Mesozoic Insects of Queensland. Part I. Introduction and Coleoptera. Queensland Geological Survey Publication 273, 1-88.

FeJfar, O. \& KaISER, T.M. 2005. Insect bone-modification and paleoecology of Oligocene mammal-bearing sites in the Doupov Mountains, northwestern Bohemia. Palaeontologia Electronica 8(8A), http://palaeo-electronica.org, 1-11.

Franzen, J.L. 1993. Das biostratigraphische Alter der Fossillagerstätte Eckfelder Maar bei Manderscheid (Eifel). Mainzer Naturwissenschaftliches Archiv 31, 201-214.

Grein, M., Utescher, T., Wilde, V. \& Roth-Nebelsick, A. 2011. Reconstruction of the middle Eocene climate of Messel using palaeobotanical data. Neues Jahrbuch für Geologie und Paläontologie, Abhandlungen 260, 305-318.

DOI 10.1127/0077-7749/2011/0139

HÁvA, J. 2003. World Catalogue of the Dermestidae (Coleoptera). Studie a zprávy Oblastního muzea Praha-východ v Brandýse nad Labem a Staré Boleslavi, Supplementum 1, 1-196.

Háva, J. 2007. Dermestidae, 57, 299-320. In Löbl, I. \& SMETANA, A. (eds) Catalogue of Palaearctic Coleoptera. Volume 4. Elateroidea - Derodontoidea - Bostrichoidea - Lymexyloidea-Cleroidea-Cucujoidea. Apollo Books, Stenstrup.

HávA, J. 2008. Globicornis rakovici n. sp., a new fossil species (Coleoptera: dermestidae: Megatomini) from Baltic amber. Alavesia 2, 3-5.

Háva, J. 2013. Description of Sodaliatoma konvickai gen. et sp. nov. (Coleoptera: Dermestidae: Megatominae) from Peru. Boletin de la Sociedad Entomológica Aragonesa 52, 113-115.

HÁva, J. \& Bukess, A. 2012. Attagenus yantarnyi sp. nov., a new species from Baltic Amber (Coleoptera: Dermestidae). Baltic Journal of Coleopterology 12, 155-158.
Háva, J. \& Prokop, J. 2004. New fossil dermestid-beetles (Coleoptera: Dermestidae) from the Dominican amber, with an appendix listing known fossil species of this family. Acta Societatis Zoologicae Bohemicae 68, 173-182.

Háva, J. \& Prokop, J. 2006. Trinodes puetzi sp. nov., a new fossil species described from the Baltic Amber (Coleoptera: Dermestidae). Acta Societatis Zoologicae Bohemicae 69, 277-279.

Háva, J., Prokop, J. \& Herrmann, A. 2006a. New fossil dermestid beetles (Coleoptera: Dermestidae) from the Baltic amber. Acta Societatis Zoologicae Bohemicae 69, 281-287.

Háva, J., Prokop, J. \& Herrmann, A. 2008. New fossil dermestid beetles (Coleoptera: Dermestidae) from the Baltic amber - III. Acta Societatis Zoologicae Bohemicae 71, 151-157.

Háva, J., Prokop, J. \& Kadej, M. 2006b. New fossil dermestid beetles (Coleoptera: Dermestidae) from the Baltic amber - II. Studies and Reports of Regional Museum Prague-East, Taxonomic Series 2, 1-14.

HeER, O. 1847. Die Insektenfauna der Tertiärgebilde von Oeningen und von Radoboj in Croatien. Erste Abteilung: Käfer. Neue Denkschriften Allgemeinen Schweizerischen Gesellschaft für die Gesammten Naturwissenschaften 9, $1-222$.

Hieke, F. \& Pietrzeniuk, E. 1984. Die Bernstein-Käfer des Museum für Naturkunde, Berlin (Insecta, Coleoptera). Mitteilungen des Zoologisches Museum Berlin 60, 297-326.

Heyden, C. \& Heyden, L. von 1865. Fossile Insekten aus der Braunkohle von Salzhausen. Palaeontographica 14, 31-35.

KAISER, T.M. 2000. Proposed fossil insect modification to fossil mammalian bone from Plio-Pleistocene hominid-bearing deposits of Laetoli (Northern Tanzania). Annals of the Entomological Society of America 93, 693-700.

DOI 10.1603/0013-8746(2000)093[0693:PFIMTF]2.0.CO;2

Kirejtshuk, A.G., Azar, D., Tafforeau, P., Boistel, R. \& FerNAndEZ, V. 2009. New beetles of Polyphaga (Coleoptera, Polyphaga) from Lower Cretaceous Lebanese amber. Denisia 86, 119-130.

Kirejtshuk, A.G., Háva, J. \& Nel, A. 2010. New genus and species of subfamily Trinodinae (Coleoptera, Polyphaga, Dermestidae) from Lowermost Eocene French amber. Zoosystematica Rossica 19, 54-69.

Kiselyova, T. \& McHugh, J. 2006. A phylogenetic study of Dermestidae (Coleoptera) based on larval morphology. Systematic Entomology 31, 469-507.

DOI 10.1111/j.1365-3113.2006.00335.x

KLOK, C.J. \& HaRrison, J.F. 2013. The Temperature Size Rule in Arthropods: Independent of Macro-Environmental Variables but Size Dependent. Integrative and Comparative Biology 53(4), 557-570. DOI 10.1093/icb/ict075

LARsson, S.G. 1978. Baltic amber - a palaeobiological study. Entomograph 1, 1-192.

Laudet, F. \& Antoine, P.-O. 2004. Des chambres de pupation de Dermestidae (Insecta: Coleoptera) sur un os de mammifère tertiaire (phosphorites du Quercy): implications taphonomiques et paléoenvironnementales. Geobios 37, 376-381. DOI 10.1016/j.geobios.2003.04.005

LAWrence, J.F. \& ŚlipińSKI, A. 2005. Three new genera of IndoAustralian Dermestidae (Coleoptera) and their phylogenetic significance. Invertebrate Systematics 19, 231-261. DOI 10.1071/IS04033

LutZ, H. 1993. Zur Taphonomie der aquatischen und terrestrischen Fauna des "Eckfelder Maares" (Mittel-Eozän; 
Deutschland): Ergebnisse aus den Grabungen 1990-1992. Mainzer Naturwissenschaftliches Archiv 31, 85-113.

Lutz, H., Frankenhäuser, H. \& NeufFer, F.O. 1998. Fossilfundstätte Eckfelder Maar - Archiv eines mitteleozänen Lebensraumes in der Eifel. 51 pp. Landessammlung für Naturkunde, Mainz.

Lutz, H., Kaulfus, U., Wappler, T., LÖhnertz, W., Wilde, V., Mertz, D.F., Mingram, J., Franzen, J.L., Frankenhäuser, H. \& Koziol, M. 2010. Eckfeld Maar: Window into an Eocene Terrestrial Habitat in Central Europe. Acta Geologica Sinica 84, 984-1009. DOI 10.1111/j.1755-6724.2010.00237.x

LutZ, H. \& NeufFer, F.O. 2000. The middle Eocene fossillagerstätte Eckfeld Maar. GFF 122, 95-96. DOI 10.1080/11035890001221095

Martin, L.D. \& West, D.L. 1995. The recognition and use of dermestid (Insecta, Coleoptera) pupation chambers in paleoecology. Palaeogeography, Palaeoclimatology, Palaeoecology 113, 303-310. DOI 10.1016/0031-0182(95)00058-T

Mertz, D.F., Swisher, C.C., Franzen, J.L., Neuffer, F.O. \& LuTZ, H. 2000. Numerical dating of the Eckfeld maar fossil site, Eifel, Germany: a calibration mark for the Eocene time scale. Naturwissenschaften 87, 270-274.

DOI $10.1007 / \mathrm{s} 001140050719$

Mingram, J. 1998. Laminated Eocene maar-like sediments from Eckfeld (Eifel region, Germany) and their short-term periodicities. Palaeogeography, Palaeoclimatology, Palaeoecology 140, 289-305. DOI 10.1016/S0031-0182(98)00021-2

NeufFer, F.O., Gruber, G., LutZ, H. \& FrankenhäUSER, H. 1996. Das Eckfelder Maar - Zeuge tropischen Lebens in der Eifel. 102 pp. Landessammlung für Naturkunde, Mainz.

Petrulevičius, J.F., Wappler, T., Wedmann, S., Rust, J. \& Nel, A. 2008. New megapodagrionid damselflies (Odonata: Zygoptera) from the Paleogene of Europe. Journal of Paleontology 82, 1173-1181. DOI 10.1666/07-091.1

PAIK, I.S. 2000. Bone chip-filled burrows associated with bored dinosaur bone in floodplain paleosols of the Cretaceous Hasandong Formation, Korea. Palaeogeography, Palaeoclimatology, Palaeoecology 157, 213-225.

DOI 10.1016/S0031-0182(99)00166-2

PIERCE, W.D. 1960. Fossil arthropods of California. 23. Silicified insects in Miocene nodules from the Calico Mountains. Bulletin of the Southern California Academy of Sciences 59, 40-49.

PIRRUNG, M., BÜCHEL, G. \& JACOBY, W. 2001. The Tertiary volcanic basins of Eckfeld, Enspel and Messel (Germany). Zeitschrift der Deutschen Geologischen Gesellschaft 152, 27-59.

Roberts, E.M., Rogers, R.R. \& Foreman, B.Z. 2007. Continental insect borings in dinosaur bone: Examples from the Late Cretaceous of Madagascar and Utah. Journal of Paleontology 81, 201-208. DOI 10.1666/0022-3360(2007)81[201:CIBIDB]2.0.CO;2

Ross, A.J. \& York, P.V. 2000. A list of type and figured specimens of insects and other inclusions in Burmese amber. Bulletin of the Natural History Museum (Geology) 56, 11-20.

SCUDDER, S.H. 1900. Adephagous and Clavicorn Coleoptera from the Tertiary deposits at Florissant, Colorado, with description of a few other forms and a sytematic list of the non-rhynchophorous Tertiary Coleoptera of North America. Monography of the United States Survey Washington 40, 3-148.

SpaHR, U. 1981. Bibliographie der Bernstein- und Kopal-Käfer
(Coleoptera). Stuttgarter Beiträge zur Naturkunde, Serie B (Geologie und Paläontologie) 72, 1-21.

WAPPLER, T. 2002. Dicranoptycha (Insecta: Nematocera: Limoniidae) aus der mitteleozänen Fossillagerstätte Eckfelder Maar bei Manderscheid / Eifel (Deutschland). Mainzer Naturwissenschaftliches Archiv 40, 129-134.

WAPPler, T. 2003a. Systematik, Phylogenie, Taphonomie und Paläoökologie der Insekten aus dem Mittle-Eozän des Eckfelder Maares, Vulkaneifel. Clausthaler Geowissenschaften 2, 1-241.

WAPPLER, T. 2003b. Die Insekten aus dem Mittel-Eozän des Eckfelder Maares, Vulkaneifel. Mainzer Naturwissenschaftliches Archiv, Beiheft 27, 1-234.

WAPPler, T. \& ANDERsen, N.M. 2004. Fossil water striders from the Middle Eocene fossil sites Eckfeld and Messel, Germany (Hemiptera, Gerromorpha). Paläontologische Zeitschrift 78, 41-52. DOI 10.1007/BF03009129

WAPPLER, T. \& ENGEL, M.S. 2003. The Middle Eocene bee faunas of the Eckfeld Maar and Messel, Germany (Hymenoptera: Apoidea). Journal of Paleontology 77, 908-921. DOI 10.1666/0022-3360(2003)077<0908:TMEBFO>2.0.CO;2

WAPPLER, T. \& ENGEL, M.S. 2006. New record of Mastotermes from the Eocene of Germany (Isoptera: Mastotermitidae). Journal of Paleontology 80, 380-385.

DOI 10.1666/0022-3360(2006)080[0380:ANROMF]2.0.CO;2

WAPPler, T., ENGEl, M.S. \& HAAs, F. 2005. The earwigs (Dermaptera: Forficulidae) from the middle Eocene Eckfeld maar, Germany. Polskie Pismo Entomologiczne 74, 227-250.

WAPPLER, T. \& HeIss, E. 2006. Flatbugs from Paleogene limnic sediments. II. Eckfeld maar (Heteroptera: Aradidae). Mainzer Naturwissenschaftliches Archiv 44, 53-60.

Wappler, T., Labandeira, C.C., Rust, J., Frankenhäuser, H. \& WILDE, V. 2012. Testing for the effects and consequences of mid Paleogene climate change on insect herbivory. PLOS ONE 7, e40744. DOI 10.1371/journal.pone.0040744

Wappler, T. \& Petrulevičius, J.F. 2007. Priscalestidae, a new damselfly family (Odonata: Lestinoidea) from the Middle Eocene Eckfeld maar of Germany. Alavesia 1, 69-73.

WAPPLER, T., SMith, V.S. \& DALgLeish, R.C. 2004. Scratching an ancient itch: an Eocene bird louse fossil. Proceedings of the Royal Society of London B (Suppl.) 271, 255-258. DOI 10.1098/rsbl.2003.0158

WiCKHAM, H.F. 1912. A report on some recent collections of fossil Coleoptera from the Miocene shales of Florissant. Bulletin from the Laboratory National History University, Iowa 6, 3-38.

Wickнам, H.F. 1913. The Princeton collection of fossil Beetles from Florissant. Annals of the Entomological Society of America 6, 359-366.

WiLdE, V. \& FRANKENHÄUSER, H. 1989. Vorläufige Mitteilungen zur Flora aus dem Alttertiär von Eckfeld-Ergebnisse einer ersten Durchsicht des Fundmaterials aus den Grabungen von 1987 und 1988. Mainzer Naturwissenschaftliches Archiv 27, 23-31.

Zhantiev, R.D. 2006. New Species of Late Eocene Dermestid Beetles (Coleoptera, Dermestidae) from the Rovno and Baltic Ambers. Paleontological Journal 40(5), 560-563. DOI 10.1134/S0031030106050108

Zherikhin, V.V.\& Ross, A.J. 2000. A review of the history, geology and age of Burmese amber (Burmite). Bulletin of the Natural History Museum 56, 3-10. 


\section{Appendix}

Geological records of Dermestidae (updated from Háva \& Prokop 2004, Kirejtshuk et al. 2009).

\begin{tabular}{|c|c|c|c|c|}
\hline Taxon & Fossil type & Epoche & Locality & References \\
\hline \multicolumn{5}{|l|}{ Subfamily Dermestinae } \\
\hline \multicolumn{5}{|l|}{ Tribe Dermestini } \\
\hline \multicolumn{5}{|l|}{ Dermestes Linnaeus } \\
\hline Dermestes larvalis Cockerell (larvae) & Inclusion & Cretaceous (Albian) & Myanmar & $\begin{array}{l}\text { Cockerell (1917), Ross \& York } \\
(2000), \text { Zherikhin \& Ross }(2000)\end{array}$ \\
\hline Dermestes pauper Heer & Compression & Early Miocene & Radoboj & Heer (1847) \\
\hline Dermestes progenior Zhantiev & Inclusion & Eocene (Lutetian) & Rovno & Zhantiev (2006), Háva (2008) \\
\hline Dermestes tertiarius Wickham & Compression & Eocene-Olicocene & Florissant, $\mathrm{CO}$ & Wickham (1912) \\
\hline Dermestes vetustus Zhantiev & Inclusion & Eocene (Lutetian) & Rovno & Zhantiev (2006), Háva (2008) \\
\hline Dermestes sp. & Inclusion & Eocene (Lutetian) & Baltic & Larsson (1978) \\
\hline Dermestes sp. & Inclusion & Eocene (Lutetian) & Baltic & Spahr (1981) \\
\hline
\end{tabular}

\section{Subfamily Attageninae}

Tribe Attagenini

Attagenus Latreille

Attagenus aboriginalis Wickham

Attagenus ambericus Háva \& Prokop

Compression Eocene-Olicocene Florissant, CO Wickham (1913)

Attagenus balticus Háva, Prokop \& Herrmann

Inclusion Miocene (Burdigalian) Dominican Republic Háva \& Prokop (2004)

Attagenus extinctus C. Heyden \& L. Heyden

Inclusion Eocene (Lutetian)

Baltic Háva et al. (2008)

Attagenus hoffeinsorum Háva, Prokop \&

Compression Middle Miocene

Salzhausen, Germany Heyden \& Heyden (1865)

Herrmann

Attagenus obesus Háva, Prokop \& Herrmann

Inclusion Eocene (Lutetian)

Baltic

Háva et al. (2006a, 2008)

Attagenus sopitus Scudder

Inclusion Eocene (Lutetian)

Baltic

Háva et al. (2008)

Attagenus yantarnyi Háva \& Bukejs

Compression Eocene-Olicocene

Florissant, CO

Scudder (1900)

Attagenus sp.

Inclusion Eocene (Lutetian)

Baltic

Háva \& Bukejs (2012)

Attagenus sp.

Inclusion Eocene (Lutetian) Baltic

Larsson (1978)

Inclusion

Eocene (Lutetian)

Baltic

Spahr (1981)

Eckfeldattagenus eocenicus gen. et sp. nov.

Compression Eocene (Lutetian)

Eckfelder maar

this study

\section{Subfamily Megatominae}

Tribe Anthrenini

Anthrenus O.F. Müller

Anthrenus sp. (larvae)

Inclusion

Eocene (Lutetian)

Baltic

Larsson (1978)

Anthrenus sp.

Inclusion

Eocene (Lutetian)

Baltic

Spahr (1981)

Anthrenus (Nanthrenus) ambericus Háva, Prokop Inclusion

Eocene (Lutetian) Baltic

Háva et al. (2006a, 2008)

Herrmann

Anthrenus (N.) electron Háva, Prokop \& Kadej Inclusion

Eocene (Lutetian) Baltic

Háva et al. (2006b)

Anthrenus (N.) groehni Háva, Prokop \& Inclusion

Eocene (Lutetian) Baltic

Háva et al. (2006a)

Herrmann

Anthrenus (N.) kerneggeri Háva, Prokop \& Inclusion

Eocene (Lutetian)

Baltic

Háva et al. (2008)

Herrmann

Tribe Megatomini

Amberoderma Háva \& Prokop

Amberoderma beali Háva \& Prokop

Inclusion

Miocene (Burdigalian) Dominican Republic Háva \& Prokop (2004)

Cryptorhopalum Guérin-Méneville

Cryptorhopalum ambericum Háva \& Prokop

Cryptorhopalum dominicanum Háva \& Prokop

Cryptorhopalum electron Beal

Inclusion

Miocene (Burdigalian) Dominican Republic Háva \& Prokop (2004)

Inclusion

Miocene (Burdigalian) Dominican Republic Háva \& Prokop (2004)

Inclusion

Miocene (Burdigalian) Mexico, Dominican Beal (1972), Háva \& Prokop (2004) Republic

Cryptorhopalum jantaricum Háva \& Prokop Inclusion Miocene (Burdigalian) Dominican 


\begin{tabular}{|c|c|c|c|c|}
\hline Taxon & Fossil type & Epoche & Locality & References \\
\hline Globicornis rakovici Háva & Inclusion & Eocene (Lutetian) & Baltic & Háva (2008) \\
\hline Globicornis sp. & Inclusion & Eocene (Lutetian) & Baltic & Larsson (1978) \\
\hline Globicornis sp. & Inclusion & Eocene (Lutetian) & Baltic & Spahr (1981) \\
\hline \multicolumn{5}{|l|}{ Megatoma Herbst } \\
\hline Megatoma electra Zhantiev & Inclusion & Eocene (Lutetian) & Baltic & Zhantiev (2006), Háva (2008) \\
\hline Megatoma sp. & Inclusion & Eocene (Lutetian) & Baltic & Hieke \& Pietrzeniuk (1984) \\
\hline \multicolumn{5}{|l|}{ Miocryptorhopalum Pierce } \\
\hline Miocryptorhopalum kirkbyae Pierce (larvae) & Compression & Miocene & Calico Mts, CA & Pierce (1960) \\
\hline \multicolumn{5}{|l|}{ Orphinus Motschulsky } \\
\hline Orphinus sp. & Inclusion & Eocene (Lutetian) & Baltic & Larsson (1978) \\
\hline Orphinus sp. & Inclusion & Eocene (Lutetian) & Baltic & Spahr (1981) \\
\hline \multicolumn{5}{|l|}{ Phradonoma Jacquelin du Val } \\
\hline $\begin{array}{l}\text { Phradonoma ambericum Háva, Prokop \& } \\
\text { Herrmann }\end{array}$ & Inclusion & Eocene (Lutetian) & Baltic & Háva et al. (2008) \\
\hline \multicolumn{5}{|l|}{ Trogoderma Dejean } \\
\hline Trogoderma larvalis Háva, Prokop \& Herrmann & Inclusion & Eocene (Lutetian) & Baltic & Hava et al. (2006a) \\
\hline Trogoderma sp. & Inclusion & Eocene (Lutetian) & Baltic & Hieke \& Pietrzeniuk (1984) \\
\hline \multicolumn{5}{|l|}{ Subfamily Orphilinae } \\
\hline \multicolumn{5}{|l|}{ Tribe Orphilini } \\
\hline \multicolumn{5}{|l|}{ Orphilus Erichson } \\
\hline Orphilus dubius Wickham & Compression & Eocene-Olicocene & Florissant, $\mathrm{CO}$ & Wickham (1912) \\
\hline \multicolumn{5}{|l|}{ Subfamily Trinodinae } \\
\hline \multicolumn{5}{|l|}{ Tribe Trinodini } \\
\hline \multicolumn{5}{|l|}{ Evorinea Beal } \\
\hline Evorinea amberica Háva, Prokop \& Herrmann & Inclusion & Eocene (Lutetian) & Baltic & Háva et al. (2008) \\
\hline \multicolumn{5}{|l|}{ Oisenodes Kirejtshuk, Háva \& Nel } \\
\hline Oisenodes azari Kirejtshuk, Háva \& Nel & Inclusion & Lowermost Eocene & Chevrière, France & Kirejtshuk et al. (2010) \\
\hline Oisenodes clavatus Kirejtshuk, Háva \& Nel & Inclusion & Lowermost Eocene & Chevrière, France & Kirejtshuk et al. (2010) \\
\hline Oisenodes gallicus Kirejtshuk, Háva \& Nel & Inclusion & Lowermost Eocene & Chevrière, France & Kirejtshuk et al. (2010) \\
\hline $\begin{array}{l}\text { Oisenodes metepisternalis Kirejtshuk, Háva } \\
\& \mathrm{Nel}\end{array}$ & Inclusion & Lowermost Eocene & Chevrière, France & Kirejtshuk et al. (2010) \\
\hline Oisenodes oisensis Kirejtshuk, Háva \& Nel & Inclusion & Lowermost Eocene & Chevrière, France & Kirejtshuk et al. (2010) \\
\hline Oisenodes transversus Kirejtshuk, Háva \& Nel & Inclusion & Lowermost Eocene & Chevrière, France & Kirejtshuk et al. (2010) \\
\hline \multicolumn{5}{|l|}{ Trinodes Dejean } \\
\hline Trinodes puetzi Háva \& Prokop & Inclusion & Eocene (Lutetian) & Baltic & $\begin{array}{l}\text { Háva \& Prokop (2006), Háva et al. } \\
\text { (2006a) }\end{array}$ \\
\hline Trinodes sp. & Inclusion & Eocene (Lutetian) & Baltic & Larsson (1978) \\
\hline Trinodes sp. & Inclusion & Eocene (Lutetian) & Baltic & Spahr (1981) \\
\hline
\end{tabular}

Tribe Cretonodini

Cretonodes Kirejtshuk \& Azar

Cretonodes antounazari Kirejtshuk \& Azar Inclusion Aptian Lebanon $\quad$ Kirejtshuk et al. (2009)

GENERA INCERTAE SEDIS

Reeveana Dunstan

\begin{tabular}{|c|c|c|}
\hline Reeveana intermedia Dunstan & Compression Late Triassic & Queensland, Australia Dunstan (1923) \\
\hline Reeveana major Dunstan & Compression Late Triassic & Queensland, Australia Dunstan (1923) \\
\hline Reeveana minor Dunstan & Compression Late Triassic & Queensland, Australia Dunstan (1923) \\
\hline \multicolumn{3}{|l|}{ Tryoniopsis Dunstan } \\
\hline Tryoniopsis granulata Dunstan & Compression Late Triassic & Queensland, Australia Dunstan (1923) \\
\hline Tryoniopsis punctata Dunstan & Compression Late Triassic & Queensland, Australia Dunstan (1923) \\
\hline
\end{tabular}

